\title{
Ellipsis
}

2015

\section{Why Gardening Is Dangerous}

Lauren E. Burgess

Follow this and additional works at: https://scholarworks.uno.edu/ellipsis

\section{Recommended Citation}

Burgess, Lauren E. (2015) "Why Gardening Is Dangerous," Ellipsis: Vol. 42 , Article 15.

DOI: https://doi.org/10.46428/ejail.42.15

Available at: https://scholarworks.uno.edu/ellipsis/vol42/iss1/15

This Poetry is brought to you for free and open access by the Department of English and Foreign Languages at ScholarWorks@UNO. It has been accepted for inclusion in Ellipsis by an authorized editor of ScholarWorks@UNO.

For more information, please contact scholarworks@uno.edu. 


\title{
Why Gardening is Dangerous
}

\author{
Lauren Burgess
}

Ryan Chighizola Prize Honorable Mention

Inspired by "When Ecstasy is Inconvenient" by Lorine Niedecker

Hear the hot day;

some lonely moon distantly whimpers.

Ask: what goes-

man's life or man's stave

into her consuming weeds?

Sower, be soft.

Know she is dead but she lived

like a rosebush by a back door

now sadly wilted,

once a gift for they who heard not

the slow grow of thorned,

ugly souls.

Learn quietly why

still some hold her seeds

in their unripe palms

and plant them. 